\title{
Sphingosine Kinases/Sphingosine-1-Phosphate and Death Signalling in APP-Transfected Cells
}

\author{
Magdalena Gassowska • Magdalena Cieslik • \\ Anna Wilkaniec $\cdot$ Joanna B. Strosznajder
}

Received: 29 August 2013/Revised: 7 December 2013/Accepted: 9 January 2014/Published online: 23 January 2014

(C) The Author(s) 2014. This article is published with open access at Springerlink.com

\begin{abstract}
It has been postulated that disturbances in the sphingolipid metabolism play a key role in the pathogenesis of Alzheimer's disease (AD). An alteration in sphingosine kinases 1, 2 (SphK1/2) and sphingosine-1phosphate (S1P) was recently reported in AD. However, the effect of AD-related amyloid beta $(\mathrm{A} \beta)$ peptides on SphK1/2 and the role of S1P in A $\beta$ toxicity have not been fully elucidated. In this study the relationship between the $\mathrm{A} \beta$ concentration and SphK1/2 expression/activity was analysed in $\mathrm{PC} 12$ cells transfected with the $\mathrm{A} \beta$ precursor protein, wild-type $\left(\mathrm{APP}_{\mathrm{wt}}\right)$ or bearing a double Swedish mutation $\left(\mathrm{APP}_{\mathrm{sw}}\right)$. The role of $\mathrm{SphK}(\mathrm{s}) / \mathrm{S} 1 \mathrm{P}$ in cell survival and death was also investigated. Our results indicated that endogenously liberated $A \beta$ significantly decreases expression and activity of SphK1/2. The SphK(s) inhibitor (SKI II, $10 \mu \mathrm{M}$ ) decreased the viability of $\mathrm{APP}_{\mathrm{wt}}, \mathrm{APP}_{\mathrm{sw}}$ as well as empty vector-transfected PC12 control cells. Our data demonstrated that expression of S1P receptor-1 (S1P1) was significantly reduced in APP-transfected cells. The effect of S1P applied exogenously was cell type-dependent. In control and $\mathrm{APP}_{\mathrm{wt}}$ cells S1P reduced the effect of the SphK1 inhibitor on death signalling. Conversely, it decreased the survival of $\mathrm{APP}_{\mathrm{sw}}$ cells and had no protective effect on cells treated with SKI II. Using the S1P1 agonist (SEW2871, $5 \mu \mathrm{M}$ ) and antagonist (W123, $20 \mu \mathrm{M}$ ), we demonstrated that the cytoprotective effect of S1P was
\end{abstract}

Magdalena Gassowska and Magdalena Cieslik have contributed equally to this study.

M. Gassowska · M. Cieslik $(\bowtie) \cdot$ A. Wilkaniec .

J. B. Strosznajder

Department of Cellular Signalling, Mossakowski Medical

Research Centre, Polish Academy of Sciences, Pawinskiego 5,

02-106 Warsaw, Poland

e-mail: cieslikmadzia@gmail.com receptor-independent. Summarising, we showed that $A \beta$ peptides evoke down-regulation of gene expression and activity for $\mathrm{SphK}(\mathrm{s})$ and S1P1. Inhibition of SphK(s) significantly decreased cell survival. The effect of exogenous S1P depended on the concentration of $A \beta$ peptides.

Keywords Alzheimer's disease - Amyloid $\beta$-peptides . Sphingolipids - Sphingosine kinases · Sphingosine-1phosphate $\cdot$ Dopaminergic cells

\section{Introduction}

Sphingosine kinases 1 (SphK1) and 2 (SphK2) are conserved lipid kinases which regulate diverse biological processes in neurons. SphK1 and SphK2 phosphorylate sphingosine to sphingosine 1-phosphate (S1P), which is a bioactive lipid mediator [1-3]. Depending on the concentration and intracellular localisation, S1P plays an important role in the regulation of cell proliferation, differentiation, and motility, and is also involved in a wide array of stress signals, which leads to growth arrest and apoptosis [4-6]. Extracellular S1P is an agonist of 5 surface G-protein-coupled receptors (GPCR), termed S1P1-5, but it may also act intracellularly as a second messenger and directly influence different cellular targets $[7,8]$. In addition to mobilising intracellular $\mathrm{Ca}^{2+}[9]$, $\mathrm{S} 1 \mathrm{P}$ can regulate histone deacetylases and the ubiquitin ligase activity of tumour necrosis factor receptor-associated factor 2 [10-12]. Stimulation of the S1P1-S1P3 receptors may activate (PI3K)/AKT, phospholipase C (PLC), extracellular signal regulated kinases $1 / 2$ (ERK1/2) or GTPases [13-15]. There have been studies which suggest that the S1P signalling response may be opposite, depending on through which kinase(s) it is generated. While SphK1 activity regulates cell growth and proliferation and exerts anti-apoptotic 
effects [16], the action of SphK2 is implicated in proapoptotic processes [17, 18]. Moreover, SphK1-dependent signalling involves inhibition of the ceramide synthases and activation of the endoplasmic reticulum S1P lyase, which is responsible for the degradation of S1P. Conversely, SphK2 activity promotes the dephosphorylation of S1P to sphingosine, which may either be re-phosphorylated or converted to ceramide [1, 18, 19]. Thus, the differential effects of the two $\operatorname{SphK}(\mathrm{s})$ may in part be due to their opposite roles in the regulation of ceramide levels.

The perturbed sphingolipid metabolism is a fundamental event in the neurodegeneration that occurs in Alzheimer's disease (AD) and other neurological disorders, including brain ischemia, hypoxia and inflammation [1]. AD, a progressive neurodegenerative disorder, is the most severe form of dementia. One important pathologic feature of $\mathrm{AD}$ is the formation of brain extracellular senile plaques, whose major components are beta-amyloid $(A \beta)$ peptides which derive from the $A \beta$ precursor protein's (APP) sequential cleavage by beta- and gamma-secretases [20, 21]. APP and the two secretases are integral membrane proteins that are located in the lipid rafts, which mainly consist of sphingolipids. Thus, lipid composition, biostat and concentration could play an important role in the trafficking of secretases and APP metabolism [22]. It has been shown that $A \beta$ interacts with plasma membrane phospholipids, thus leading to changes in the biophysical properties of the bilayer and causing disturbances in the sphingolipids, glycosphingolipids and cholesterol that may alter the function of lipid rafts [23].

Both an increased level of ceramide and a sphingosine/ S1P rheostat imbalance are observed from the earliest clinically recognisable stages of $\mathrm{AD}$ [1]. In vivo studies showed a decrease in the concentration of S1P and ceramide accumulation which was proportional to the degree of cognitive impairment, loss of intellectual ability and loss of neurons [2, 23, 24]. Moreover, dramatic changes in other sphingolipid content were also demonstrated, e.g. ceramides and galactoceramides were increased while sulfatides and phospholipids were reduced. Recent studies showed an increased level of ceramide with a simultaneous decrease in sphingomyelin levels in the brain and in the cerebrospinal fluid of AD patients as compared with samples from healthy elderly donors [1, 23, 24]. Increased amounts of sphingosine with concomitant decreased levels of S1P were also found in cytosolic fractions prepared from AD brains [1, 22]. Additionally, in those preparations the profile of sphingolipid metabolising enzymes was shifted towards promotion of ceramide synthesis [1].

It has been indicated that sphingolipids, the fundamental component of lipid rafts, influence the proteolytic cleavage of APP and the production of A $\beta$. Ceramide as well as S1P produced by SphK2 enhance $A \beta$ generation by posttranslational stabilisation of $\beta$-site APP cleaving enzyme-1 (BACE-
1). In contrast, sphingomyelin (SM) decreases $A \beta$ production by inhibition of the $\gamma$-secretase [2, 23-25]. A $\beta$ may in turn cause deregulation of the sphingolipid metabolism. An in vitro study showed that $A \beta_{42}$ down-regulates SM through activation of neutral sphingomyelinase (nSMase), which leads to an increased level of ceramide, a mediator of $\mathrm{A} \beta$-inducted apoptosis [24, 26]. Under pathological conditions such as AD, cleavage of APP and A $\beta$ generation are probably responsible for deregulated sphingolipid homeostasis [24].

The significance of $A \beta$ in the alteration of sphingosine kinases/S1P and their involvement in the regulation of cell viability are not well understood. The aim of our study was to investigate the relationship between the level of $\mathrm{A} \beta$ and SphK1/2 expression/activity and its role in cell survival and death. Moreover, the effect of exogenously added S1P on cell viability was evaluated in an experimental model of AD.

\section{Materials and Methods}

\section{Chemicals}

The following antibodies were used in the current study: anti-SphK1 (Cell Signalling, Beverly, MA, USA), antiGAPDH, anti-rabbit IgG (Sigma-Aldrich, St. Louis, MO, USA). Reagents for reverse transcription (High Capacity RNA-to-cDNA Master Mix) and PCR (Gene Expression Master Mix) were from Applied Biosystems (Applied Biosystems, Foster City, CA, USA). NBD-Sphingosine was obtained from Avanti Polar Lipids (Alabaster, AL, USA). Cell culture reagents: Dulbecco's modified Eagle's medium (DMEM), fetal bovine serum (FBS), horse serum (HS), penicillin, streptomycin, G418, L-glutamine and other reagents such as: deoxyribonuclease I, 3-(4,5-dimethyl-2-tiazolilo)-2,5-diphenyl-2H-tetrazolium bromide (MTT), TRI-reagent, polyethylenoimine (PEI), dimethyl sulfoxide (DMSO) and all other common reagents were from Sigma-Aldrich (St. Louis, MO, USA). Specific SphK(s) inhibitor: 4-[4-(4-chloro-phenyl)-thiazol-2-ylamino]-phenol (SKI II) was obtained from Sigma-Aldrich (St. Louis, MO, USA). N,N-dimethylsphingosine (DMS) was obtained from Biomol (Plymouth, PA, USA). 2-Amino-4octadecene-1,3-diol 1-phosphate (S1P) was from Enzo Life Sciences (Lausen, Switzerland). 5-[4-phenyl-5-(trifluoromethyl)-2-thienyl]-3-[3-(trifluoromethyl)phenyl]-1,2,4oxadiazole (SEW-2871) and 3-(2-(3-hexylphenylamino)-2oxoethylamino)propanoic acid (W123) were from Cayman Chemical (Ann Arbor, MI, USA).

\section{Cell Culture}

Rat pheochromocytoma (PC12) cells and their derivative clones stably expressing human APP were a kind gift from 
Dr. W. E. Mueller (University of Frankfurt, Frankfurt am Main, Germany). The studies were carried out using: empty vector-transfected cells (PC12), cells transfected with the human wild-type APP gene $\left(\mathrm{APP}_{\mathrm{wt}}\right)$, and cells transfected with the Swedish mutated (K670M/N671L) gene $\left(\mathrm{APP}_{\mathrm{sw}}\right)$. All cell lines were cultured in DMEM supplemented with $10 \%$-heat-inactivated FBS and $5 \%$ heat-inactivated $\mathrm{HS}, 50 \mathrm{U} / \mathrm{ml}$ penicillin/streptomycin, $2 \mathrm{mM}$ L-glutamine and $400 \mu \mathrm{g} / \mathrm{ml}$ G418. Cells were maintained at $37{ }^{\circ} \mathrm{C}$ in a humidified incubator in $5 \% \mathrm{CO}_{2}$ atmosphere.

\section{Cell Treatment Protocols}

Equal PC12 cell numbers were seeded into 96-well $0.1 \%$ polyethyleneimine-coated plates or $35 \mathrm{~mm}^{2}$ dishes and after $24 \mathrm{~h}$ the growth medium was changed to a low-serum medium (DMEM supplemented with $2 \% \mathrm{FBS}, 50 \mathrm{U} / \mathrm{ml}$ penicillin/streptomycin and $2 \mathrm{mM}$ L-glutamine). Then the PC12 cells were treated with SphK kinases inhibitor: SKIII $(10 \mu \mathrm{M}), \mathrm{S} 1 \mathrm{P}(1 \mu \mathrm{M})$, selective agonist of S1P1: SEW$2871(5 \mu \mathrm{M})$, and selective antagonist of S1P1: W123 $(20 \mu \mathrm{M})$, for $24 \mathrm{~h}$.

\section{Determination of Cell Survival Using the MTT Test}

Cell viability was evaluated by reduction of 2-(4,5-dimethylthiazol-2-yl)-2,5-diphenyltetrazolium bromide (MTT) to formazan. After $24 \mathrm{~h}$ of treatment with the tested compounds, MTT $(2.5 \mathrm{mg} / \mathrm{ml})$ was added to all of the wells. The cells were incubated at $37{ }^{\circ} \mathrm{C}$ for $2 \mathrm{~h}$. Then the medium was removed, the formazan crystals were dissolved in DMSO and absorbance at $595 \mathrm{~nm}$ was measured.

\section{Quantitative Real-Time PCR}

Reverse transcription was performed using a High Capacity cDNA Reverse Transcription Kit according to the manufacturer's protocol (Applied Biosystems, Foster City, CA, USA). The level of mRNA for selected genes was analysed using TaqMan Gene Expression Assays (Applied Biosystems, Foster City, CA, USA) according to the manufacturer's instructions. $A c t b$ was selected and used in all studies as a reference gene. Plates were analysed on an ABI PRISM 7500 apparatus. The relative level of mRNA was calculated using the $\Delta \Delta \mathrm{Ct}$ method.

\section{Western Blot Analysis}

Cells were washed three times with ice-cold PBS and lyzed. Protein levels were determined using the Lowry method, and then the samples were mixed with Laemmli buffer and denatured at $95{ }^{\circ} \mathrm{C}$ for $5 \mathrm{~min}$. After standard
$10 \%$ SDS-PAGE separation, the proteins were transferred to a PVDF membrane and used for immunochemical detection. The membranes were washed for 5 min in TBST buffer (100 mM Tris-buffered saline, $140 \mathrm{mM} \mathrm{NaCl}$ and $0,1 \%$ Tween 20) ( $\mathrm{pH} 7.6$ ) and the nonspecific bindings were blocked for $60 \mathrm{~min}$ at $\mathrm{RT}$ in a $5 \%$ non-fat milk solution in TBS-T buffer. After blocking, the membranes were incubated with the primary antibody (rabbit polyclonal anti-SphK1 antibody) used at a dilution of 1:250 in TBS-T buffer, overnight at $4{ }^{\circ} \mathrm{C}$. The membranes were then washed three times ( 5 min each) in TBS-T buffer and incubated for $60 \mathrm{~min}$ at RT with a secondary antibody (anti-rabbit antibody $\mathrm{IgG}$ ) at a dilution of 1:4,000 in a $5 \%$ non-fat milk/TBS-T solution. Then after four washing steps ( $3 \times 5 \mathrm{~min}$ in TBS-T buffer, $1 \times 5 \mathrm{~min}$ in TBS buffer) antibodies were detected by a chemiluminescent reaction (ECL reagent) (Amersham Biosciences) under standard conditions. After stripping, the immunolabeling of GAPDH was performed on membranes as a loading control in standard conditions.

\section{Determination of $\operatorname{SphK}(\mathrm{s})$ Activity}

Sphingosine kinases activity assay was performed according to a previous report [17]. After $24 \mathrm{~h}$ incubation, cells were washed with iced PBS and lysed by freeze-thaw cycle in $50 \mathrm{mM}$ HEPES $\left(10 \mathrm{mM} \mathrm{KCl}, 15 \mathrm{mM} \mathrm{MgCl}_{2}\right.$, $0.1 \%$ Triton $\mathrm{X}-100,20 \%$ glycerol, $2 \mathrm{mM}$ orthovanadate, $2 \mathrm{mM}$ dithiothreitol, $10 \mathrm{mM} \mathrm{NaF}, 1 \mathrm{mM}$ deoxypyridoxine, and EDTA-free complete protease inhibitor) ( $\mathrm{pH} 7.4$ ) (Roche Applied Science). Lysates were cleared by centrifugation at $15.000 \mathrm{rpm}$ for $5 \mathrm{~min}$. The lysates and NBDSphingosine $(10 \mu \mathrm{M}$ final) (Avanti Polar Lipids) were mixed in the reaction buffer (50 mM HEPES, $15 \mathrm{mM}$ $\mathrm{MgCl}_{2}$ and $0.5 \mathrm{mM} \mathrm{KCl}, 10 \%$ glycerol and $2 \mathrm{mM} \mathrm{ATP}$ ) (pH 7.4) and incubated for $30 \mathrm{~min}$ at $30{ }^{\circ} \mathrm{C}$. The reactions were stopped by the addition of equal amount of $1 \mathrm{M}$ potassium phosphate ( $\mathrm{pH} 8.5$ ), followed by addition of 2.5fold chloroform/methanol (2:1), and then centrifuged at $15.000 \mathrm{rpm}$ for $1 \mathrm{~min}$. Only the reactant NBD-S1P, but not the substrate NBD-Sphingosine, was collected in alkaline aqueous phase. After aqueous phase was combined with an equal amount of dimethylformamide, the fluorescence value was read $\left(\lambda_{\mathrm{ex}}=485 \mathrm{~nm}, \lambda_{\mathrm{em}}=538 \mathrm{~nm}\right)$ [27].

\section{Statistical Analysis}

The results were expressed as mean values \pm SEM. Differences between the means were analysed using a Student's $t$ test for two groups or one-way analysis of variance ANOVA with Bonferroni's post hoc test among multiple groups. Statistical significance was accepted at $p<0.05$. The statistical analyses were performed using Graph Pad 
Prism version 4.0 (Graph Pad Software, San Diego, CA, USA).

\section{Results}

To study the deregulation of the sphingolipid metabolism induced by $\mathrm{A} \beta$ peptides, we used $\mathrm{PC} 12$ cells stably transfected with wild-type APP $\left(\mathrm{APP}_{w t}\right)$ and APP with the Swedish double mutation $\left(\mathrm{APP}_{\mathrm{sw}}\right)$ which secreted, respectively, 2.8 and 4.8 times more $\mathrm{A} \beta$ as compared to the PC12 control cells [20, 28]. Ultrastructural analysis revealed that in $\mathrm{APP}_{\mathrm{sw}}$ overexpressing cells there was formation of an intracellular network of randomly orientated fibrous aggregates of $A \beta$ [29]. By using this in vitro model we observed that endogenously liberated $A \beta$ significantly decreased expression of sphingosine kinase 1 (SphK1, Fig. 1a) and sphingosine kinase 2 (SphK2, Fig. 1b) with concomitant decline in SphK1 protein level (Fig. 1c). This effect, however, did not depend on the concentration of $A \beta$ in cells and was comparable for both $\mathrm{APP}_{\mathrm{wt}}$ and $\mathrm{APP}_{\mathrm{sw}}$ cells. As presented in Fig. 1c the immunoreactivity of SphK1 was significantly reduced by about $50 \%$ in $\mathrm{APP}_{\mathrm{wt}}$ cells and only by about $25 \%$ in $\mathrm{APP}_{\mathrm{sw}}$ cells. In contrast to changes in gene expression and protein level, the activity of $\mathrm{SphK}(\mathrm{s})$ was significantly reduced in APP transfected cells in A $\beta$ concentration dependent manner. The $\operatorname{SphK}(\mathrm{s})$ activity was substantially lower in the $\mathrm{APP}_{\mathrm{sw}}$ cells when compared to the $\mathrm{APP}_{\mathrm{wt}}$ cells (Fig. 2).

To test whether alteration of SphK(s) may have deleterious consequences, we studied the effect of their inhibition on cell viability. The MTT test revealed that less specific $\operatorname{SphK}(\mathrm{s})$ inhibitor (DMS) and a more specific (SKI II) inhibitor of SphK1 reduced PC12 control cell viability in a dose-dependent manner, causing, respectively, the death of 33 and $70 \%$ of cells at a $50 \mu \mathrm{M}$ concentration (Fig. 3a). Endogenously liberated $\mathrm{A} \beta$ did not significantly decrease viability of the $\mathrm{APP}_{\mathrm{wt}}$ and $\mathrm{APP}_{\mathrm{sw}}$ cells (MTT test) after $24 \mathrm{~h}$ of cultivation (Fig. 3b). The specific SphK(s) inhibitor (SKI II, $10 \mu \mathrm{M}$ ) had a negative effect on the viability both APP-transfected and PC12 control cell line (Fig. 3b).

Cell death induced by SKI II may occur due to reduced production of S1P, the main product of enzymatic activity of $\operatorname{SphK}(\mathrm{s})$. In this experimental condition the level of sphingosine and subsequently ceramide should increase, thus causing disturbances in the sphingolipid rheostat. In the following experiments the role of S1P on cell viability was investigated. This sphingolipid did not have an effect on the viability of PC12 control and $\mathrm{APP}_{\mathrm{wt}}$ cells in control conditions (Fig. 4); however, it significantly protected those cells against death induced by $\operatorname{SphK}(\mathrm{s})$ inhibition (Fig. 4). Interestingly, S1P caused a decrease of $\mathrm{APP}_{\mathrm{sw}}$ cell
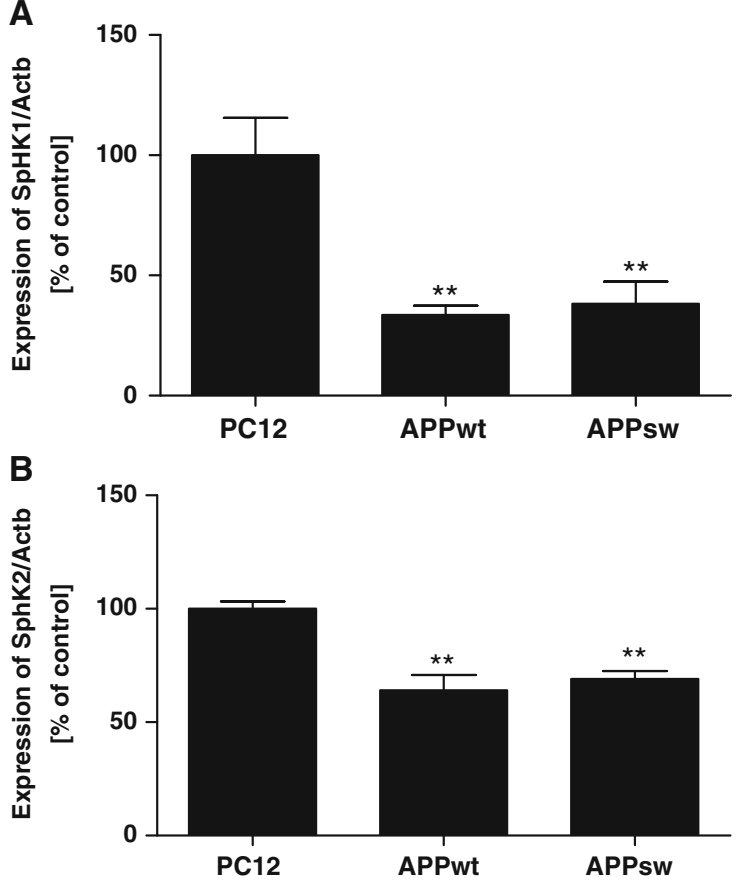

C

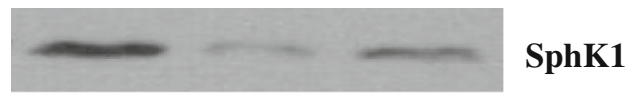

GAPDH

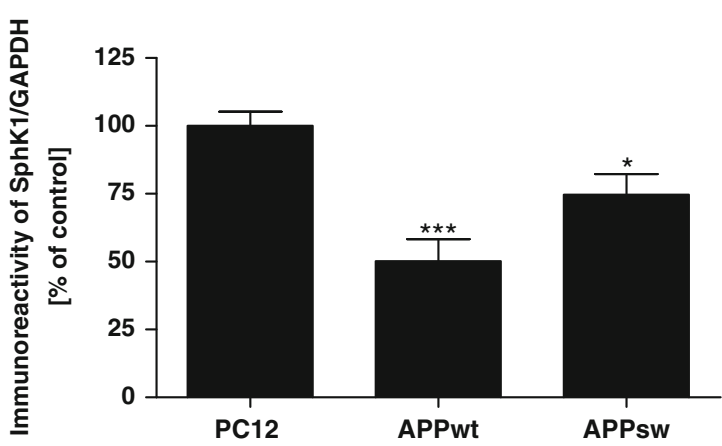

Fig. 1 Level of mRNA for SphK1 and SphK2 and protein level of SphK1 in APP-transfected cells. Gene expression for SphK1 (a) and SphK2 (b) was measured with real-time PCR. (c) Total level of SphK1 normalized by GAPDH was determined using Western blot analysis. Data represent the mean value \pm SEM for six independent experiments carried out in triplicate. ${ }^{* *} p<0.01$ versus PC12 cells (cells transfected with an empty vector); ${ }^{* * *} p<0.001$ versus PC12 cells; $* p<0.05$ versus PC1 2 cells, using one-way ANOVA followed by Bonferroni's Multiple Comparison Test

viability and was ineffective when those cells were subjected to SKI II (Fig. 4).

Subsequently, we investigated the mechanism of the protective effect of $\mathrm{S} 1 \mathrm{P}$ in $\mathrm{PC} 12$ control and $\mathrm{APP}_{\mathrm{wt}}$ cells. To test whether sphingosine 1 phosphate receptor-1 (S1P1) was involved in this phenomenon, we used a specific agonist of S1P1 (SEW2871, $5 \mu \mathrm{M}$ ); however, we did not 


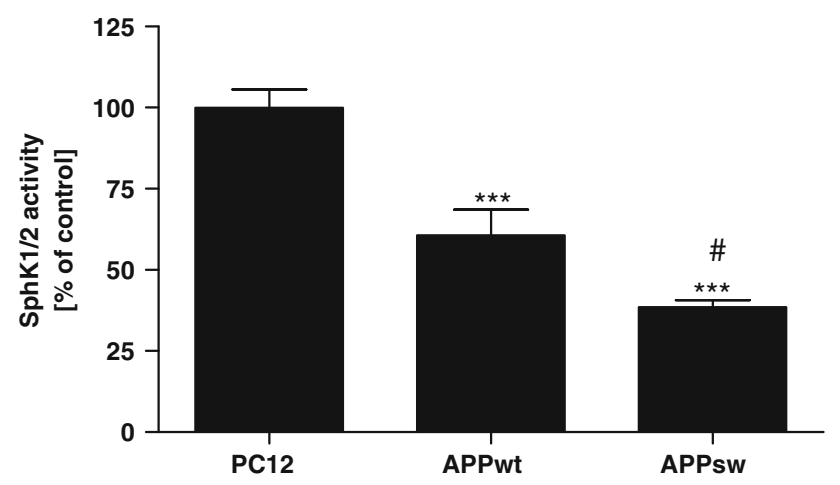

Fig. 2 The SphK1/2 activity in APP-transfected cells. The activity of $\mathrm{SphK}(\mathrm{s})$ was determined spectrofluorimetically with NBD-Sphingosine as described in "Materials and Methods" section. Data represent the mean value \pm SEM for six independent experiments carried out in triplicate. $* * * p<0.001$ versus $\mathrm{PC} 12$ cells; ${ }^{\#} p<0.05$ versus $\mathrm{APP}_{\mathrm{wt}}$ cells using a one-way ANOVA followed by Bonferroni's Multiple Comparison Test

observe the beneficial effect of this compound on any of the cell lines that were tested (Fig. 5).

Additionally, the selective antagonist of S1P1 (W123, $20 \mu \mathrm{M}$ ) induced cell death exclusively in APP-transfected cells, and exogenously added S1P did not have any effect on this negative action (Fig. 6). Moreover, expression of $\mathrm{S} 1 \mathrm{P}$ receptor-1 was significantly decreased in both $\mathrm{APP}_{\mathrm{wt}}$ and $\mathrm{APP}_{\mathrm{sw}}$ cells (Fig. 7), which may explain the observed ineffectiveness of SEW2871 and suggest that the protective effect of S1P is not mediated by S1P1.

\section{Discussion}

Recent data demonstrated that sphingolipid metabolism alteration may play a crucial role in the ethiopathology of AD. An increased amount of sphingosine and a decreased amount of S1P were found in the cytosolic fraction prepared from the autopsies of AD brains [2], thus suggesting that the activity of S1P synthesising/degrading enzymes may be greatly disturbed in the course of dementia.

A major finding of the present study is that endogenously liberated $A \beta$ peptides caused a significant decrease in the expression of SphK1 and 2 in APP-transfected PC12 cell lines. These data correspond to previous findings which indicated that exposure to $A \beta_{25-35}$, the neurotoxic fragment of the $A \beta$ peptide, induced strong inhibition of SphK1 in neuronal SHSY5Y cells. However, in those experimental conditions $A \beta_{25-35}$ did not significantly alter the SphK2. The data of Gomez-Brouchet et al. [30] demonstrated that knock down of SphK1 expression in SHSY5Y cells resulted in activation of the intrinsic pathway of apoptosis. This involved enhanced Bax oligomerisation, mitochondrial membrane permeabilisation,
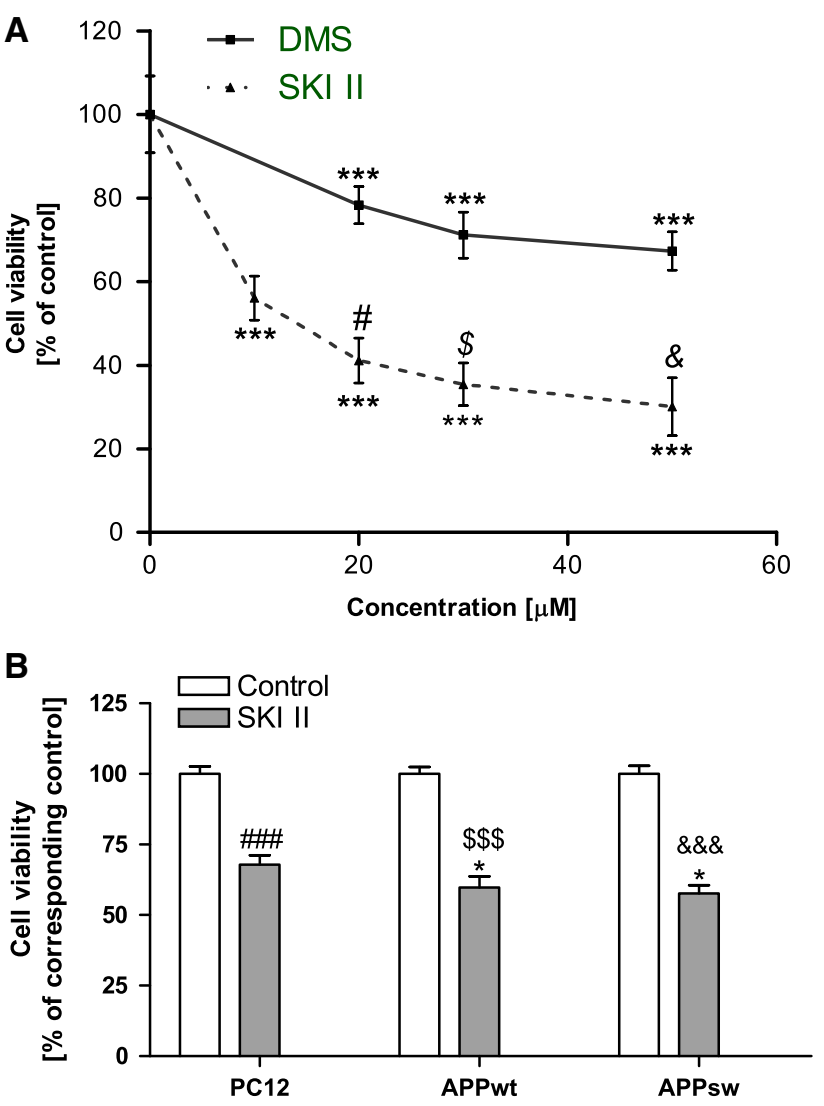

Fig. 3 Effect of SphK inhibitors on the viability of PC12 and APPtransfected cells. Cell viability was determined spectrophotometrically using the MTT assay. (a) Concentration-dependent effect of SphK(s) inhibitors: DMS and SKI II on the viability of PC12 cells after $24 \mathrm{~h}$ incubation. (b) Effect of SphK(s) inhibitor: SKI II $(10 \mu \mathrm{M})$ on APP-transfected cell viability. Data represent the mean value \pm SEM for three separate experiments carried out in triplicate. $*_{* *} p<0.001$ versus control (non-treated) PC12 cells; ${ }^{*} p<0.001$ versus $20 \mu \mathrm{M}$ DMS-treated PC12 cells; ${ }^{\$} p<0.001$ versus $30 \mu \mathrm{M}$ DMS-treated PC12 cells; ${ }^{\&} p<0.001$ versus $50 \mu \mathrm{M}$ DMS-treated PC12 cells; \#\#\# $p<0.0001$ versus non-treated PC12 cells; $\$ \$ p<0.0001$ versus non-treated $\mathrm{APP}_{\mathrm{wt}}$ cells; ${ }^{\& \& \&} p<0.0001$ versus non-treated $\mathrm{APP}_{\mathrm{sw}}$ cells; $* p<0.05$ versus SKI II-treated PC12 cells, using one-way ANOVA followed by Bonferroni's Multiple Comparison Test

cytochrome c release and caspase activation [30]. Interestingly, these marked changes in the $\mathrm{SphK}(\mathrm{s})$ expression level were not correlated with an alteration of cell viability in our APP-transfected cells. These data indicated that simultaneously of cytoprotective events may occur in these cells.

SphK(s) are largely cytosolic enzymes that have been postulated to migrate to membranes where they can phosphorylate sphingosine to bioactive sphingolipid S1P [3134]. However, a high concentration of SphK1 was also detected in the nucleus. Transient or stable overexpression of SphK1 in NIH 3T3 fibroblasts or HEK293 cells, with a concomitant increased level of S1P, protected against 


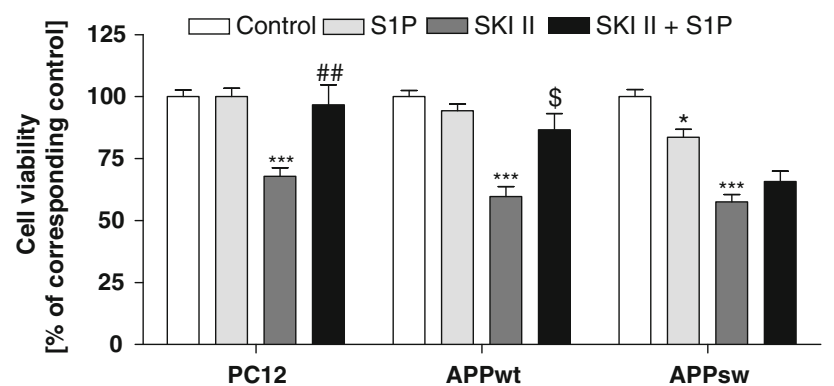

Fig. 4 Effect of S1P on SKI II-evoked decrease in cell viability. PC12 and APP-transfected cells were pre-incubated with $1 \mu \mathrm{M} \mathrm{S1P}$ for $5 \mathrm{~min}$, and then $10 \mu \mathrm{M}$ SKI II was added for $24 \mathrm{~h}$. Cell viability was spectrophotometrically determined using the MTT assay. Data represent the mean value \pm SEM for three separate experiments carried out in triplicate. ${ }^{*} p<0.05$ versus non-treated $\mathrm{APP}_{\mathrm{sw}}$ cells; $* * * p<0.001$ versus corresponding control; ${ }^{\# \#} p<0.01$ versus SKI IItreated PC1 2 cells; ${ }^{\$} p<0.05$ versus SKI II-treated $\mathrm{APP}_{\mathrm{wt}}$ cells, using one-way ANOVA followed by Bonferroni's Multiple Comparison Test

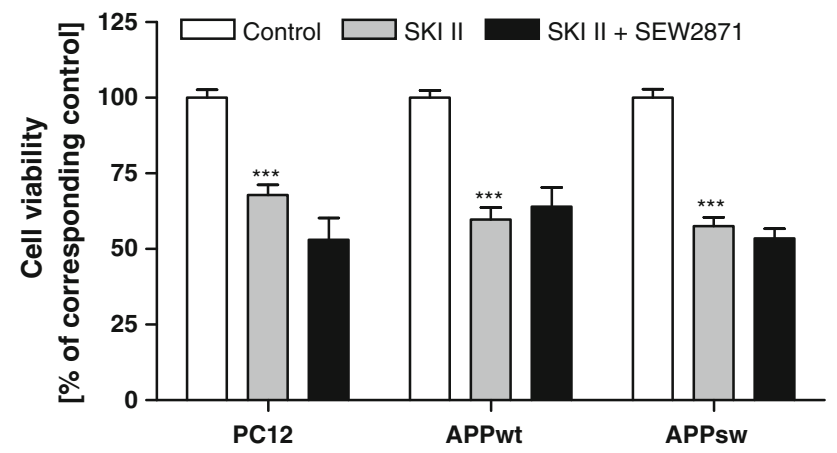

Fig. 5 Effect of S1P1 agonist on SKI II-evoked decrease in cell viability. Cells were incubated with $10 \mu \mathrm{M}$ SKI II in the presence of $5 \mu \mathrm{M}$ SEW2871 for $24 \mathrm{~h}$. Cell viability was spectrophotometrically determined using the MTT assay. Data represent the mean value \pm SEM for three separate experiments carried out in triplicate. *** $p<0.001$ versus corresponding control, using one-way ANOVA followed by Bonferroni's Multiple Comparison Test

apoptosis which was induced by serum deprivation or ceramide elevation. Endogenous S1P has been reported to regulate intracellular $\mathrm{Ca}^{2+}$ mobilisation and to promote cell growth and survival [31,35]. However, excessive accumulation of S1P may also have a neurotoxic effect, thus causing disruption of ER calcium homeostasis [13].

S1P is short-lived, so the synthetic process catalysed by SphK may be important in maintaining the compound's cellular levels. Our data show that S1P supplementation exerted a protective effect on $\mathrm{PC} 12$ and $\mathrm{APP}_{\mathrm{wt}}$ cell viability which was significantly decreased by SphK1 inhibition. However, in the $\mathrm{APP}_{\mathrm{sw}}$ cells, which were characterised by 4.8 times more $\mathrm{A} \beta$ secretion as compared to the $\mathrm{PC} 12$ control [20, 28], this effect was not observed. Moreover, $\mathrm{S} 1 \mathrm{P}$ decreased the viability of the $\mathrm{APP}_{\mathrm{sw}}$ cells. A study by Takasugi et al. [17] reported up-regulation of SphK2 activity in $\mathrm{AD}$ brains and a positive correlation between SphK2 activity and APP processing. SphK2 activity promotes S1P formation, which may activate the $\beta$-site APP cleaving enzyme-1 (BACE-1), thus leading to higher liberation of $A \beta$ peptides [17]. S1P was shown to specifically bind to full-length BACE-1 and to increase its proteolytic activity; then this pool of S1P is dephosphorylated to sphingosine and may be either re-phosphorylated by SphK2 or converted to ceramide $[1,17-19]$. Thus, the addition of extracellular S1P in $\mathrm{APP}_{\mathrm{sw}}$ cells may result in an elevation of $A \beta$ and ceramide levels which is responsible for cell death. Pharmacological or genetic inhibition of SphK2 in APP transgenic mice significantly reduced $A \beta$ levels, thus further suggesting the direct involvement of SphK2/S1P in $\mathrm{A} \beta$ generation in vivo $[17,21]$. The influence of S1P in $A \beta$ release may also be proved by our data, which show that $\mathrm{S} 1 \mathrm{P}$ itself had a deleterious effect in $\mathrm{APP}_{\mathrm{sw}}$ cells. This suggests that excessive $A \beta$ release may be responsible for disturbance of the $\operatorname{SphK}(\mathrm{s})$ and ceramide/S1P biostat, which could be a regulator of cell survival and death in our experimental conditions. In line with this hypothesis, it was demonstrated that transient or stable overexpression of SphK1 in NIH 3T3 fibroblasts or HEK293 cells protected against apoptosis induced by serum deprivation or ceramide elevation [36]. Similar data were obtained by Edsall et al. [16], showing that overexpression of SphK1 promotes cell survival in PC12 cells exposed to $\mathrm{C}_{2}$-ceramide by increasing the intracellular S1P level with a concomitant reduction of both ceramide and sphingosine production [16]. Moreover, SphK1 overexpression prevented apoptosis by blocking activation of caspase-2, -3 and -7 and the stressactivated protein kinase, c-Jun amino terminal kinase (SAPK/JNK) [22]. On the contrary, SphK1 down-regulation was associated with an accumulation of ceramide and, in consequence, with cell death [37-41]. Moreover, S1P itself had a deleterious effect in those cells.

It is well known that S1P may act intracellularly as a second messenger $[8,42]$ or extracellularly as a ligand for the G protein-coupled receptors S1P1 to S1P5 [43, 44]. A growing body of evidence suggests that $\mathrm{SphK}(\mathrm{s})$ and S1P receptors may play an important role in the pathogenesis of $\mathrm{AD}$ and other neurodegenerative disorders, such as multiple sclerosis (MS), HIV and dementia. Here we showed that the protective effect of S1P in PC12 control and $\mathrm{APP}_{\mathrm{wt}}$ cells was independent of sphingosine-1-phosphate receptor-1 (S1P1) activation. The specific agonist of S1P1 (SEW2871) did not exert a beneficial effect. Our data demonstrated that A $\beta$ peptides significantly decreased expression of S1P1. The experiment of Kaneider et al. [44] demonstrated $\mathrm{A} \beta_{39-43}$-dependent regulation of $\mathrm{SphK}(\mathrm{s})$ activity and S1P receptor expression in human monocytes. Induction of S1P2 and S1P5 mRNA in $A \beta_{39-43}$ treated cells was indicated [44]. 


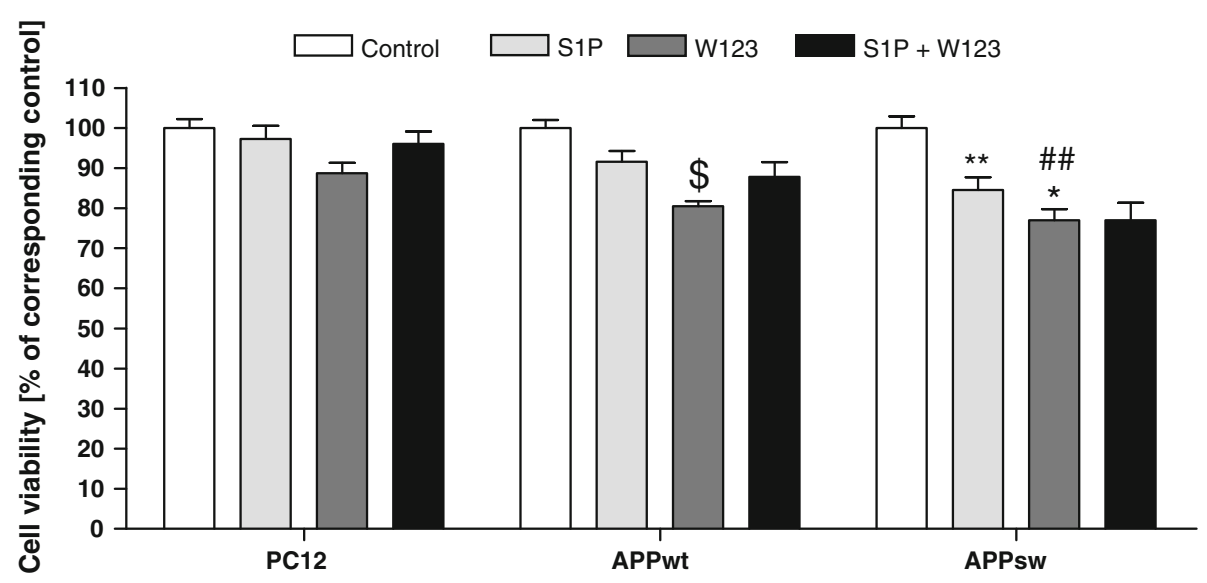

Fig. 6 Effect of S1P on S1P1 antagonist-evoked decrease in cell viability. Cells were incubated with $1 \mu \mathrm{M}$ S1P in the presence of $20 \mu \mathrm{M} \mathrm{W} 123$ for $24 \mathrm{~h}$. Cell viability was spectrophotometrically determined using the MTT assay. Data represent the mean value \pm SEM for three separate experiments carried out in triplicate.

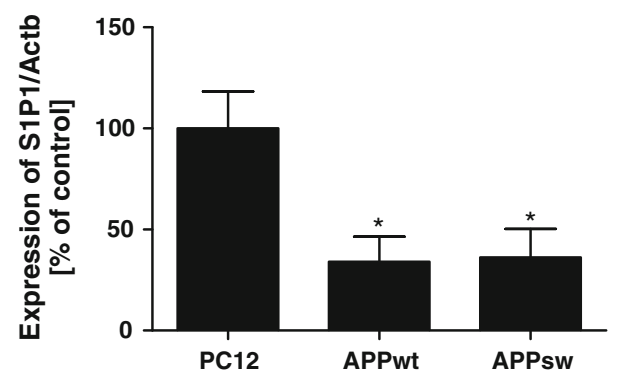

Fig. 7 Expression of S1P1 in APP-transfected cells. Gene expression was measured with real-time PCR. Data represent the mean value \pm SEM for three independent experiments carried out in triplicate. $* p<0.05$ versus PC12 cells, using one-way ANOVA followed by Bonferroni's Multiple Comparison Test

Summarising, we observed decreased expression and activity of SphK1/2 as well as of the expression of S1P1 receptor in APP-transfected cells secreting a different amount of $A \beta$ peptides. Moreover, our data demonstrated that the cytoprotective effect of S1P against death evoked by $\operatorname{SphK}(\mathrm{s})$ inhibition was not mediated by S1P1 and depended on the type of cells and the $A \beta$ concentration. The capability of $A \beta$ to modulate the sphingolipid metabolism suggests that this deregulation may be a crucial event that occurs in the course of degeneration.

Acknowledgments This study was supported by MS\&HE Grant 5870/B/PO1/2011/40

Open Access This article is distributed under the terms of the Creative Commons Attribution License which permits any use, distribution, and reproduction in any medium, provided the original author(s) and the source are credited. $\$_{p}<0.05$ versus non-treated $\mathrm{APP}_{\mathrm{wt}}$ cells; ${ }^{\# \#} p<0.01$ versus nontreated $\mathrm{APP}_{\mathrm{sw}}$ cells; $* p<0.05$ versus $\mathrm{W} 123$-treated $\mathrm{PC} 12$ cells; $* * p<0.05$ versus non-treated $\mathrm{APP}_{\mathrm{sw}}$ cells, using one-way ANOVA followed by post hoc Bonferroni's Multiple Comparison Test

\section{References}

1. Haughey NJ, Bandaru VVR, Bae M, Mattson MP (2010) Roles for dysfunctional sphingolipid metabolism in Alzheimer's disease neuropathogenesis. Biochim Biophys Acta 1801:878-886

2. Katsel P, Li C, Haroutunian V (2007) Gene expression alterations in the sphingolipid metabolism pathways during progression of dementia and Alzheimer's disease: a shift toward ceramide accumulation at the earliest recognizable stages of Alzheimer's disease? Neurochem Res 32:845-856

3. Fukuda Y, Kihara A, Igarashi Y (2003) Distribution of sphingosine kinase activity in mouse tissues: contribution of SPHK1. Biochem Biophys Res Commun 309(1):155-160

4. Muller G, Ayoub M, Storz P, Rennecke J, Fabbro D, Pfizenmaier $\mathrm{K}$ (1995) PKC is a molecular switch in signal transduction of TNF-a, bifunctionally regulated by ceramide and arachidonic acid. EMBO J 14:1961-1969

5. Riboni L, Viani P, Bassi R, Giussani P, Tettamanti G (2001) Basic fibroblast growth factor-induced proliferation of primary astrocytes. Evidence for the involvement of sphingomyelin biosynthesis. J Biol Chem 276:12797-12804

6. Pettus BJ, Chalfant CE, Hannun YA (2002) Ceramide in apoptosis: an overview and current perspectives. Biochim Biophys Acta 1585:114-125

7. Alvarez SE, Milstien Sh, Spiegel S (2007) Autocrine and paracrine roles of sphingosine-1-phosphate. Trends Endocrinol Metab 18:300-307

8. Pyne NJ, Pyne S (2010) Sphongosine 1-phosphate and cancer. Nat Rev Cancer 10:489-503

9. Van Brocklyn JR, Lee MJ, Menzeleev R, Olivera A, Edsall L, Cuvillier O, Thomas DM, Coopman PJ, Thangada S, Liu CH, Hla T, Spiegel S (1998) Dual actions of sphingosine-1-phosphate: extracellular through the Gi-coupled receptor Edg-1 and intracellular to regulate proliferation and survival. J Cell Biol 142:229-240

10. Pitson SM (2011) Regulation of sphingosine kinase and sphingolipid signaling. Trends Biochem Sci 36:97-107

11. Hait NC, Allegood J, Maceyka M, Strub GM, Harikumar KB, Singh SK, Luo C, Marmorstein R, Kordula T, Milstien S, Spiegel S (2009) Regulation of histone acetylation in the nucleus by sphingosine-1-phosphate. Science 325:1254-1257 
12. Alvarez SE, Harikumar KB, Hait NC, Allegood J, Strub GM, Kim EY, Maceyka M, Jiang H, Luo C, Kordula T, Milstien S, Spiegel S (2010) Sphingosine-1-phosphate is a missing cofactor for the E3 ubiquitin ligase TRAF2. Nature 465(7301):1084-1088

13. Hagen N, Hans M, Hartmann D, Swandulla D, Van EchtenDeckert G (2011) Sphingosine-1-phosphate links glycosphingolipid metabolism to neurodegeneration via a calpain-mediated mechanism. Cell Death Differ 18:1356-1365

14. Hannun YA, Obeid LM (2008) Principles of bioactive lipid signalling: lessons from sphingolipids. Nat Rev Mol Cell Biol 9(2):139-150

15. Meyer zu, Heringdorf D, Jakobs KH (2007) Lysophospholipid receptors: signalling, pharmacology and regulation by lysophospholipid metabolism. Biochim Biophys Acta 1768:923-940

16. Edsall LC, Cuvillier O, Twitty Sh, Spiegel S, Milstien Sh (2001) Sphingosine kinase expression regulates apoptosis and caspase activation in PC12 cells. J Neurochem 76:1573-1584

17. Takasugi N, Sasaki T, Suzuki K, Osawa S, Isshiki H, Hori Y, Shimada N, Higo T, Yokoshima S, Fukuyama T, Lee V, Trojanowski JQ, Tomita T, Iwatsubo T (2011) BACE1 activity is modulated by cell-associated sphingosine-1-phosphate. J Neurosci 31(18):6850-6857

18. Maceyka M, Sankala H, Hait NC et al (2005) Sphk1 and Sphk2: sphingosine kinase isoenzymes with opposing functions in sphingolipid metabolism. J Biol Chem 280:37118-37129

19. Strub GM, Maceykaa M, Hait NC, Milstienb S, Spiegel S (2010) Extracellular and intracellular actions of sphingosine-1-phosphate. Adv Exp Med Biol 688:141-155

20. Epis R, Marcello E, Gardoni F, Di Luca M (2012) Alpha, betaand gamma-secretases in Alzheimer's disease. Front Biosci (Schol Ed) 4:1126-1150

21. Zinser EG, Hartmann T, Grimm MOW (2007) Amyloid beta-protein and lipid metabolism. Biochim Biophys Acta 1768:1991-2001

22. Van Echten-Deckert G, Walter J (2012) Sphingolipids: critical players in Alzheimer's disease. Prog Lipid Res 51:378-393

23. Lütjohann D, Meichsner S, Pettersson H (2012) Lipids in Alzheimer's disease and their potential for therapy. Discl Clin Lipidol 7(1):65-78

24. Grimm MOW, Rothhaar TL, Hartmann T (2012) The role of APP proteolytic processing in lipid metabolism. Exp Brain Res 217:365-375

25. Tamboli IY, Prager K, Barth E, Heneka M, Sandhoff K, Walter J (2005) Inhibition of glycosphingolipid biosynthesis reduces secretion of the $\beta$-amyloid precursor protein and amyloid $\beta$ peptide. J Biol Chem 280(30):28110-28117

26. Grimm MOW, Grimm HS, Hartmann T (2007) Amyloid beta as a regulator of lipid homeostasis. Trends Mol Med 13(8):337-344

27. Billich A, Ettmayer P (2004) Fluorescence-based assay of sphingosine kinases. Anal Biochem 326(1):114-119

28. Chalimoniuk M, Stolecka A, Cakała M, Hauptmann S, Shulz K, Lipka U, Leuner K, Eckert A, Muller WE, Strosznajder BJ (2007) Amyloid beta enhances cytosolic phospholipase A2 level and arachidonic acid release via nitric oxide in APP-transfected PC12 cells. Acta Biochim Pol 54(3):611-623

29. Pająk B, Songin M, Strosznajder BJ, Orzechowski A, Gajkowska B (2009) Ultrastructural evidence of amyloid $\beta$-induced autophagy in PC12 cells. Folia Neuropathol 47(3):252-258
30. Gomez-Brouchet A, Pchejetski D, Brizuela L, Garcia V, Altie' M-F, Maddelein M-L, Delisle M-B, Cuvillier O (2007) Critical role for sphingosine kinase-1 in regulating survival of neuroblastoma cells exposed to amyloid- $\beta$ peptide. Mol Pharmacol 72:341-349

31. Olivera A, Spiegel S (2001) Sphingosine kinase: a mediator of vital cellular functions. Prostaglandins Lipid Med 64:123-134

32. Young KW, Willets JM, Parkinson MJ, Bartlett P, Spiegel S, Nahorski SR, Challiss RA (2003) Ca2/calmodulin-dependent translocation of sphingosine kinase: role in plasma membrane relocation but not activation. Cell Calcium 33:119-128

33. Jolly PS, Bektas M, Watterson KR, Sankala H, Payne SG, Milstien S, Spiegel S (2005) Expression of SphK1 impairs degranulation and motility of RBL-2H3 mast cells by desensitizing S1P receptors. Blood 105(12):4736-4742

34. Wattenberg BW, Pitson SM, Raben DM (2006) The sphingosine and diacylglycerol kinase superfamily of signaling kinases: localization as a key to signalling function. J Lipid Res 47: $1128-1139$

35. Young KW, Nahorski SR (2002) Sphingosine 1-phosphate: a $\mathrm{Ca}^{2+}$ release mediator in the balance. Cell Calcium 32:335-341

36. Olivera A, Kohama T, Edsall L, Nava V, Cuvillier O, Poulton S, Spiegel S (1999) Sphingosine kinase expression increases intracellular sphingosine-1-phosphate and promotes cell growth and survival. J Cell Biol 147(3):545-558

37. Nava VE, Cuvillier O, Edsall LC, Kimura K, Milstien S, Gelmann EP, Spiegel S (2000) Sphingosine enhances apoptosis of radiationresistant prostate cancer cells. Cancer Res 60:4468-4474

38. Taha TA, Osta W, Kozhaya L, Bielawski J, Johnson KR, Gillanders WE, Dbaibo GS, Hannun YA, Obeid LM (2004) Downregulation of sphingosine kinase-1 by DNA damage: dependence on proteases and p53. J Biol Chem 279:20546-20554

39. Pchejetski D, Golzio M, Bonhoure E, Calvet C, Doumerc N, Garcia V, Mazerolles C, Rischmann P, Teissie J, Malavaud B et al (2005) Sphingosine kinase-1 as a chemotherapy sensor in prostate adenocarcinoma cell and mouse models. Cancer Res 65:11667-11675

40. Bonhoure E, Pchejetski D, Aouali N, Morjani H, Levade T, Kohama T, Cuvillier O (2006) Overcoming MDR-associated chemoresistance in HL-60 acute myeloid leukemia cells by targeting sphingosine kinase-1. Leukemia 20:95-102

41. Takabe K, Paugh SW, Milstein S, Spiegel S (2008) "Inside-out" signalling of sphingosine-1-phosphate: therapeutic targets. Pharmacol Rev 60:181-195

42. Ozaki H, Hla T, Lee MJ (2003) Sphingosine-1-phosphate signaling in endothelial activation. $\mathrm{J}$ Atheroscler Thromb 10:125-131

43. Rosen H, Goetzl EJ (2005) Sphingosine 1-phosphate and its receptors: an autocrine and paracrine network. Nat Rev Immunol $5: 560-570$

44. Kaneider NC, Lindner J, Feistritzer C, Sturn DH, Mosheimer BA, Djanani AM, Wiedermann ChJ (2004) The immune modulator FTY720 targets sphingosine-kinase dependent migration of human monocytes in response to amyloid beta-protein and its precursor. FASEB J 18(11):1309-1311 